\title{
Octylphenol does not mimic diethylstilbestrol-induced oestrogen receptor- $\alpha$ expression in the newborn mouse uterine epithelium after prenatal exposure
}

\author{
M Nielsen ${ }^{1,2}$, P E Høyer ${ }^{3}$, J G Lemmen ${ }^{4}$, B van der Burg ${ }^{4}$ and \\ A G Byskov ${ }^{2}$ \\ ${ }^{1}$ Department of Clinical Studies, Reproduction, The Royal Veterinary and Agricultural University, Copenhagen, Denmark \\ ${ }^{2}$ Laboratory of Reproductive Biology, Juliane Marie Center for Children, Women and Reproduction, University Hospital of Copenhagen, Denmark \\ ${ }^{3}$ Institute of Medical Anatomy, The Panum Institute, University of Copenhagen, Denmark \\ ${ }^{4}$ Hubrecht Laboratory, Netherlands Institute for Developmental Biology, Utrecht, The Netherlands \\ (Requests for offprints should be addressed to M Nielsen, Laboratory of Reproductive Biology, Juliane Marie Center for Children, Women and Reproduction, \\ Rigshospitalet Section 5712, University Hospital of Copenhagen, Blegdamsvej 9, DK-2100 Copenhagen, Denmark; Email: majken.Irb@rh.dk)
}

\begin{abstract}
This study examined whether the endocrine disruptor octylphenol (OP) mimics the synthetic oestrogen diethylstilbestrol (DES) in ability to induce oestrogen receptor- $\alpha$ $(E R-\alpha)$ expression in the newborn mouse uterine epithelium after prenatal exposure. Pregnant mice were given daily s.c. injections with DES (10 or $100 \mu \mathrm{g}$ DES $/ \mathrm{kg}$ maternal wt) or OP (100 or $250 \mathrm{mg} / \mathrm{kg}$ maternal wt) or with vehicle alone from day 11.5 to $16 \cdot 5$ of pregnancy. ER- $\alpha$ expression was evaluated on histological sections by detecting ER- $\alpha$ mRNA with the in situ hybridization technique and ER- $\alpha$ protein using immunohistochemistry. The immunostaining was quantitated using a microspectrophotometer. Oestrogen-like activity of the DES and $\mathrm{OP}$ batches used for in vivo exposure was confirmed in
\end{abstract}

an in vitro assay based on transient gene expression of an oestrogen-dependent reporter plasmid. In mice exposed prenatally to vehicle alone, the uterine epithelium did not express either ER- $\alpha$ mRNA or protein, while both were highly expressed in the stroma. Exposure to either DES dose induced the expression of both ER- $\alpha$ mRNA and protein in the epithelium, whereas it was unchanged in the stroma. In contrast, neither OP dose induced the expression of ER- $\alpha$ mRNA or protein in the epithelium and expression was unchanged in the stroma. Our data stress the importance of in vivo studies when investigating endocrine disruptors.

Journal of Endocrinology (2000) 167, 29-37

\section{Introduction}

During the last decades, increasing incidents of abnormally developed reproductive organs and reproductive dysfunctions have been reported in human and wildlife populations (Crisp et al. 1998). Environmental chemicals are being increasingly suspected for their possible participation in inducing such effects. They are proposed to possess hormone-like properties such as mimicking natural hormones and/or inhibiting the action of hormones. The chemicals constitute a large group of man-made and naturally occurring compounds in the environment and are often referred to as endocrine disruptors. It is well documented that prenatal exposure to the synthetic oestrogen diethylstilbestrol (DES) induces various reproductive alterations in humans (Bibbo et al. 1977, Gill et al. 1979, Wilcox et al. 1995) and mice (McLachlan et al. 1975, 1980, Newbold 1995). Numerous reproductive changes in wildlife populations suggested to be caused by endocrine disruptors resemble those induced by DES (Crisp et al. 1998). Therefore, suspected endocrine disruptors are traditionally examined for their ability to mimic oestrogen-like effects.

The mechanisms by which endocrine disruptors produce an effect are uncertain. However, induction of oestrogen-like effects might involve the oestrogen receptors. So far two subtypes of nuclear oestrogen receptors, oestrogen receptor- $\alpha$ (ER- $\alpha$ ) and oestrogen receptor- $\beta$ (ER- $\beta$ ) (Kuiper et al. 1996, Mosselman et al. 1996, Tremblay et al. 1997) have been identified, and the existence of a membrane-associated oestrogen receptor has been reported (Nemere \& Farach-Carson 1998). A number of fast and low-cost in vitro screening systems based on binding to and induction of effects via nuclear oestrogen receptors have been developed in order to assess the oestrogenicity of endocrine disruptors (Pelissero et al. 1993, Makela et al. 1994, White et al. 1994, Soto et al. 1995, Arnold et al. 1996, Coldham et al. 1997, Kuiper 
et al. 1998, Legler et al. 1999). Such assays are very useful for preliminary screening but obviously present difficulties in extrapolation to the in vivo situation in which uptake, distribution and metabolism is involved in the biological activity of a compound. Another drawback of in vitro assays is the limited number of cellular signalling pathways as compared with the in vivo situation. Thus, when studying endocrine disruptors and their possible influence on reproductive function, in vivo experiments seem to be unavoidable.

Reproductive organs are highly susceptible to hormonal exposure during a critical phase of foetal life, when they form and sex differentiate. It is therefore believed that exposure to DES or endocrine disruptors during foetal life might be detrimental to the development and differentiation of the reproductive organs, although abnormalities may not be expressed until adulthood (Bern 1992). Neonatal exposure of mice to oestradiol or DES, at concentrations which later in life lead to the development of abnormalities in the female genital tract including the uterus, has been shown to induce nuclear oestrogen receptor expression in the uterine epithelium (Andersson \& Forsberg 1988, Sato et al. 1992, 1996). Prenatal DES exposure and changes in oestrogen receptor expression in mice have only been examined in one study, which showed induction similar to that after neonatal exposure (Newbold 1995). The mechanism behind such DESand oestradiol-induced changes in oestrogen receptor expression is unknown. However, when studying endocrine disruptors it seems pertinent to examine their capability to mimic various DES-like changes, e.g. induction of oestrogen receptor expression in the uterus.

One of the suspected endocrine disruptors is the alkylphenol 4-tert-octylphenol (OP). It is a widely distributed degradation product of octylphenol ethoxylates used in household products such as detergents and emulsifiers, as well as in agricultural and industrial applications. OP is weakly oestrogenic in in vitro assays (White et al. 1994, Soto et al. 1995, Arnold et al. 1996) and in the traditional utero-tropic assay it possesses oestrogen-like activity by increasing the uterus weight (Bicknell et al. 1995). Based on such assays, $\mathrm{OP}$ is regarded as an oestrogenic compound with potential impact on reproductive health. However, detailed examinations of whether OP induces effects resembling oestradiol or DES effects at the cellular level are few. In the present study we tested whether OP mimics DES-induced ER- $\alpha$ expression in the uterine epithelium of the newborn mouse after prenatal exposure. ER- $\alpha$ expression was evaluated by detecting ER- $\alpha$ mRNA by in situ hybridization and ER- $\alpha$ protein by immunohistochemistry. Quantitation of immunostaining was evaluated using a microspectrophotometer. The DES and $\mathrm{OP}$ batches used for in vivo exposure were tested in an in vitro assay in order to confirm their oestrogen-like activity.

\section{Materials and Methods}

\section{In vivo exposure}

Mature mice, strain NMRI (Bomholtgaard, Denmark) were maintained under constant conditions with a photoperiod of $12 \mathrm{~h}$ light (beginning at $0800 \mathrm{~h}$ ) and $12 \mathrm{~h}$ darkness. Food and water were supplied and animals were allowed to feed ad libitum. The morning after mating, female mice were examined for the presence of a vaginal plug. The day when the plug was present was designated day 0.5 post coitum (p.c.) and the term for delivery was day 19 p.c. The timed pregnant mice were given daily s.c. injections from day 11.5 p.c. to 16.5 p.c. of either DES (Sigma, Copenhagen, Denmark) or OP (Aldrich, Copenhagen, Denmark) dissolved in peanut oil, or of vehicle alone. The daily doses were 10 or $100 \mu \mathrm{g}$ DES $/ \mathrm{kg}$ maternal wt and 100 or $250 \mathrm{mg} \mathrm{OP} / \mathrm{kg}$ maternal wt. In preliminary experiments an even higher dose of $\mathrm{OP}$ $(500 \mathrm{mg} / \mathrm{kg}$ per day) was tested. This dose turned out to be toxic, as four out of six pregnant mice died. On the day of birth, the female genital system including ovary, oviduct and uterine horns was removed from the newborns and fixed appropriately for either in situ hybridization or immunohistochemistry. Those DES-treated mice which did not deliver on the expected day were delivered by caesarean section on day 19 p.c. Tissue from each of the five treated groups of animals will in the following be referred to as DES10, DES100, OP100, OP250 and control respectively.

\section{In situ hybridization}

Tissue fixed overnight in $4 \% \mathrm{w} / \mathrm{v}$ paraformaldehyde at $4{ }^{\circ} \mathrm{C}$ was embedded in paraffin. Sections $(6 \mu \mathrm{m}$ thick) were mounted on TESPA (3-aminopropyltriethoxysilane)-coated glass slides and dried overnight at $42{ }^{\circ} \mathrm{C}$. Tissue from three to four animals originating from two to four litters from each group of treated animals was processed in this manner. Uteri from adult mice in which ER- $\alpha$ mRNA expression is high, served as positive control tissue for the in situ hybridization procedure.

To detect murine ER- $\alpha$ mRNA, anti-sense and sense ${ }^{35} \mathrm{~S}$-labelled riboprobes for the ligand binding domain were generated as described previously (Lemmen et al. 1999). An FspI/XbaI fragment of mouse oestrogen receptor cDNA spanning amino residues 929-1204 was ligated into pBluescript cut with both SmaI and XbaI. To generate the anti-sense riboprobe, the plasmid was linearized with EcoRI and subsequently transcribed with T3 RNA-polymerase in the presence of $\alpha{ }^{35}$ S-UTP (Amersham, Roosendaal, The Netherlands). The sense probe was transcribed by T7 RNA polymerase using $\alpha{ }^{-35}$ S-UTP after the plasmid was linearized with SacI.

In situ hybridization was conducted as described by Feijen et al. (1994). The sections were subjected to pre-treatment with $20 \mu \mathrm{g} / \mathrm{ml}$ proteinase $\mathrm{K}$ in order to 
increase accessibility, and $0.25 \% \mathrm{v} / \mathrm{v}$ acetic anhydride to reduce background. The probe $\left(1 \times 10^{5}\right.$ c.p.m. $\left./ \mu \mathrm{l}\right)$ was applied and hybridization was carried out overnight at $55^{\circ} \mathrm{C}$ in a moist chamber. The hybridization was terminated by removing the coverslips in $5 \times$ SSC (SSC: $0 \cdot 15 \mathrm{M}$ $\mathrm{NaCl}, 0.015 \mathrm{M}$ Na citrate, $\mathrm{pH} 7 \cdot 4), 25 \mathrm{mM}$ DTT at $50{ }^{\circ} \mathrm{C}$. The sections were then washed at high stringency for $30 \mathrm{~min}$ at $65{ }^{\circ} \mathrm{C}$ in a solution of $50 \%$ formamide, $2 \times$ SSC, $100 \mathrm{mM}$ DTT. Subsequently, non-specifically bound probes were removed by treatment with $20 \mu \mathrm{g} / \mathrm{ml}$ RNase A at $37^{\circ} \mathrm{C}$ for $30 \mathrm{~min}$ followed by a wash at high stringency. The sections were washed at room temperature in $2 \times$ SSC and $0 \cdot 1 \times$ SSC each for 15 min and dehydrated in ethanol supplemented with $300 \mathrm{mM}$ ammonium acetate and air-dried. Ilford G5 photo emulsion was used for autoradiography and diluted 1:1 with $2 \%$ glycerol-water. The sections were exposed for 2 weeks at $4{ }^{\circ} \mathrm{C}$, developed in Kodak D19, fixed in Kodak UNIFIX, and subsequently counterstained with haematoxylin. The sections were examined using a light microscope.

\section{Immunohistochemistry}

The tissue was fixed overnight at $4{ }^{\circ} \mathrm{C}$ in $4 \% \mathrm{w} / \mathrm{v}$ formaldehyde, $\mathrm{pH} 5 \cdot 0$, followed by dehydration and embedding in paraffin. Sections ( $5 \mu \mathrm{m}$ thick) were cut and mounted on SuperFrost-Plus glass slides (Prohosp, Værløse, Denmark) and dried for $1 \mathrm{~h}$ at $60{ }^{\circ} \mathrm{C}$. Uteri from 18-19-day-old prepubertal mice were used as positive control tissue for the immunohistochemical procedure, as this tissue is well known for its high expression of oestrogen receptors. For each group of treated animals, tissue from five to eight animals originating from four to five litters was processed for immunohistochemistry. On each day of immunohistochemical staining, sections from at least one animal from the control group were included.

The immunohistochemical procedure for localization of ER- $\alpha$ has been described previously (Nielsen et al. 2000). Briefly, the deparaffinated sections were subjected to antigen retrieval in $0.01 \mathrm{M}$ citrate buffer $(\mathrm{pH} 6 \cdot 0)$ by microwaving. The endogenous peroxidase was then blocked by incubating the sections in $0 \cdot 3 \% \mathrm{H}_{2} \mathrm{O}_{2}$. A monoclonal ER-antibody raised to the $\mathrm{N}$-terminal (A/B) region of the human oestrogen receptor (DAKO A/S, Glostrup, Denmark) diluted 1:100 in 1\% w/v BSA was applied to the sections which were left to incubate for $1 \mathrm{~h}$ at room temperature. The ER antibody has been shown to recognize ER- $\alpha$ (Al Saati et al. 1993) and does not cross-react with ER- $\beta$ (Pettersson et al. 1997). As a control, sections were incubated in parallel with $1 \%$ BSA, either without antibody or supplemented with irrelevant mouse $\operatorname{IgG}$ at the same concentration as used for the ER antibody. Biotinylated secondary antibodies (LSAB+ Kit) were added for $15 \mathrm{~min}$ followed by the application of peroxidase-conjugated streptavidin (LSAB+ Kit) for $15 \mathrm{~min}$. The peroxidase was visualized by applying 3,3'- diaminobenzidine chromogen solution $(\mathrm{DAB}+)$ for $5 \mathrm{~min}$. Reagents used for visualization were obtained from DAKO A/S, Glostrup, Denmark. The reaction was ended by washing the sections in running tap water, whereupon the sections were dehydrated and mounted with Pertex.

\section{Quantitation of immunostained sections and statistical evaluation}

The intensity of immunostaining was quantitated with a Vickers M85A scanning and integrating microspectrophotometer (Vickers, York, UK) employing the following procedure. The distal part of the longitudinally cut uteri was sought out by using the built-in differential interference contrast system of the instrument. In this way, feebly stained or even unstained nuclei could easily be identified. In the direction of where the uterine horns originally were connected to the corpus, the nuclei of the first 10-15 epithelial cells and the first 15-20 stroma cells were selected in each of at least two consecutive sections. In this way at least 20 epithelial cell nuclei and 30 stroma cell nuclei were selected for measurement in each specimen. Overlapping nuclei were omitted. Subsequently, the nuclei were scanned with the following machine settings. $\times 40$ objective (scanning area $28 \cdot 3 \mu \mathrm{m}^{2}$ ), light at the absorption maximum $(460 \mathrm{~nm})$ of the polymerized $\mathrm{DAB}$ reaction product and a scanning spot diameter of $0.5 \mu \mathrm{m}^{2}$. Within each area, the instrument automatically integrated the individual spot readings. The mean integrated absorbance over all areas was then calculated by reference to a standard calibration graph, constructed by measuring a series of neutral density filters with known absorbance values. The microspectrophotometer was calibrated on each experimental day whereby any day-to-day variation in the sensitivity of the instrument was eliminated. Moreover, measurements of the neutral density filters showed that the instrument was linear within the range of the absorbance values recorded in the nuclei. Finally, the mean polymerized $\mathrm{DAB}$ reaction product measured in the absence of the primary antibody (i.e. the control section incubated with $1 \%$ BSA without ER antibody) was subtracted from that measured in the presence of antibody to give a measure of the specific antibody binding alone. The slides were decoded at the end of the experiment. The data were processed using version four of the StatGraphics Plus statistical software package (STSC, Rockville, MD, USA). The results for each experimental group are expressed as medians and ranges. The differences between multiple samples were assessed by the Kruskal-Wallis analysis of variance and were identified by a posteriori evaluation (Conover 1980) using a 95\% confidence limit.

\section{Transient gene expression assay}

In order to evaluate whether the DES and OP batches used in this study were biologically active, an in vitro 

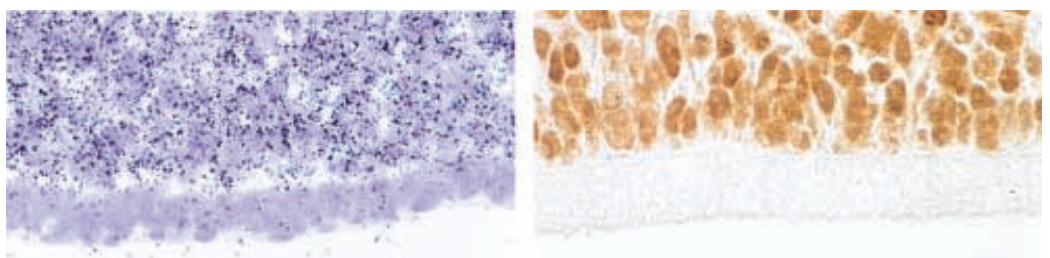

a

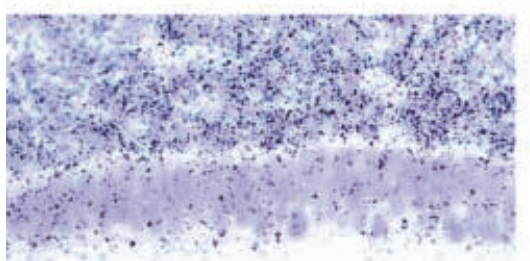

\section{$\mathrm{C}$}

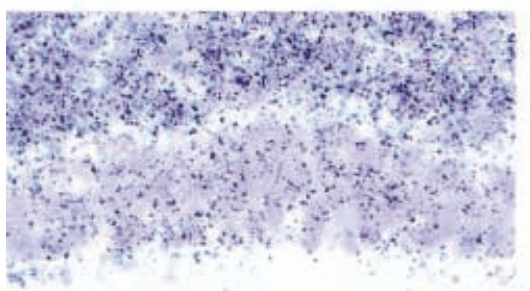

\section{e}

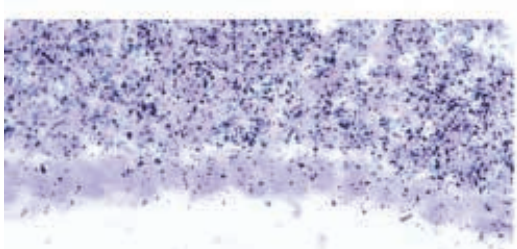

\section{g}
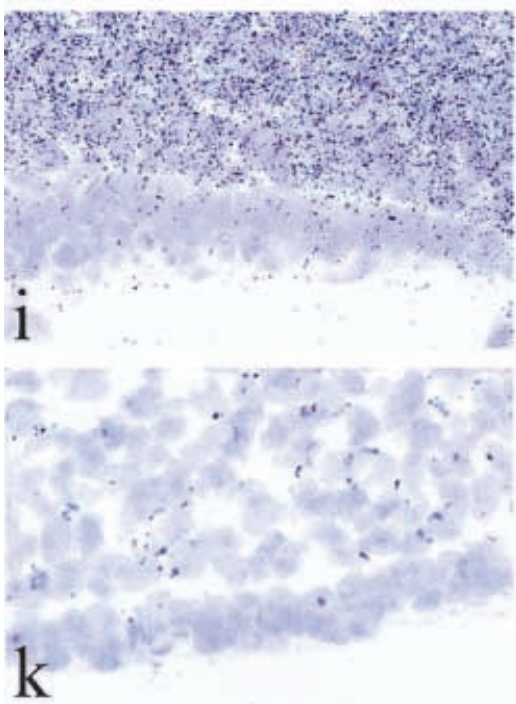

b

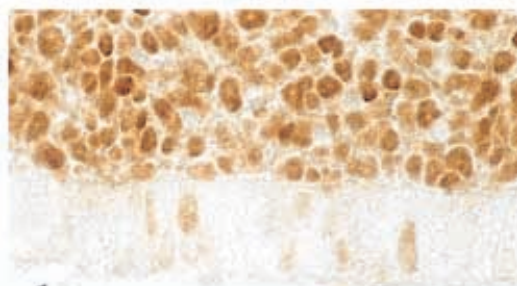

d

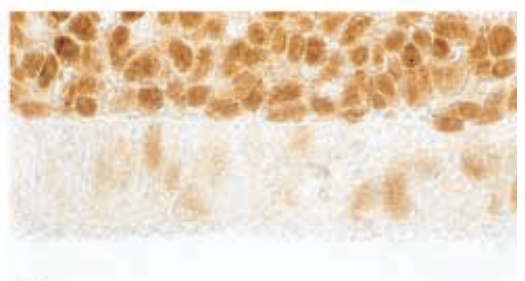

f

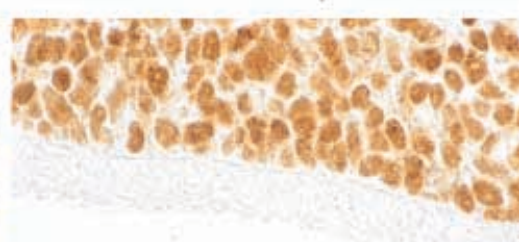

$\mathrm{h}$
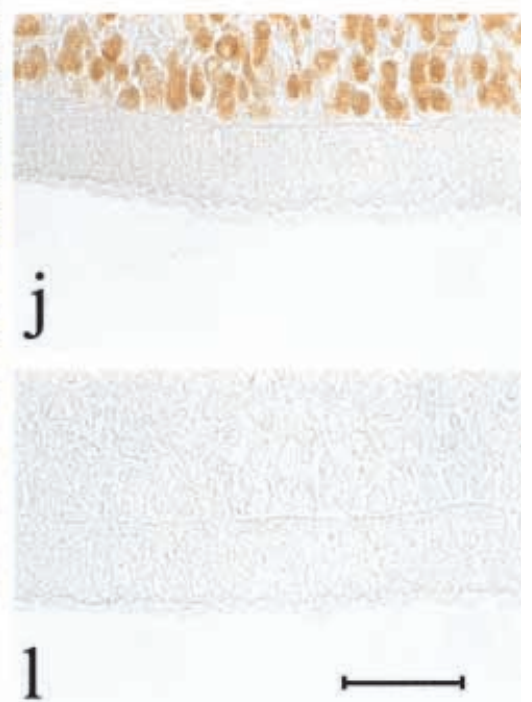
transient gene expression assay was performed. The induction of gene activity was tested in a cell-based transcription assay system, using a reporter gene under transcriptional control of ER- $\alpha .17 \beta$-oestradiol $\left(\mathrm{E}_{2}\right)$ (Sigma, Zwijndrecht, The Netherlands) was included as a positive control compound. The oestrogen-responsive reporter gene construct (3 xERE-TATA-LUC) with three copies of a consensus oestrogen response element (ERE) containing oligonucleotide and a TATA box in front of the luciferase cDNA was used (Kuiper et al. 1998). The human ER- $\alpha$ expression plasmid pSG5-HEGO (kindly provided by Dr P Chambon, IGBMC, Strasbourg, France) was used. Human 293 embryonal kidney cells obtained from the ATCC (American Type Culture Collection, Rockville, MD, USA) were cultured in a 1:1 mixture of DMEM and Ham's F12 medium (DF) supplemented with $7 \cdot 5 \% \mathrm{v} / \mathrm{v}$ FCS. Subsequent to trypsinization, the cells were suspended in phenol-free DF medium containing $30 \mathrm{nM}$ selenite, $10 \mu \mathrm{g} / \mathrm{ml}$ transferrin and $0 \cdot 2 \% \mathrm{v} / \mathrm{v}$ BSA, supplemented with $5 \% \mathrm{v} / \mathrm{v}$ charcoal-stripped FCS and plated out in 24-well tissue culture plates. After $24 \mathrm{~h}$ the cells were transfected by calcium phosphate precipitation (Chu \& Sharp 1981) with $1 \mu \mathrm{g} 3$ xERE-TATA-LUC, $0 \cdot 4 \mu \mathrm{g}$ SV2-LacZ (Pfahl et al. 1990) internal control plasmid and $0 \cdot 2 \mu \mathrm{g}$ pSG5-HEGO per well. The medium was changed after $16 \mathrm{~h}$ and $0.8 \mu \mathrm{l}$ of a range of concentrations of $\mathrm{E}_{2}$, DES and OP (dissolved in ethanol) was added directly to $0.8 \mathrm{ml}$ of medium. The resulting concentrations for $\mathrm{E}_{2}$ and DES were $10^{-13}-10^{-8} \mathrm{M}$, and $10^{-9}-10^{-5} \mathrm{M}$ for $\mathrm{OP}$. After $24 \mathrm{~h}$ exposure, the cells were lysed in lysis solution (1\% v/v Triton X-100, $25 \mathrm{mM}$ glycylglycine, $15 \mathrm{mM}$ $\mathrm{MgSO}_{4}, 4 \mathrm{mM}$ EGTA and $1 \mathrm{mM}$ dithiothreitol (DTT)). The luciferase activity of the cell lysates was measured with the Luclite luciferase reporter gene assay system (Packard Instruments, Meriden, CT, USA), according to the manufacturer's instructions. The $\beta$-galactosidase activity was measured in order to correct for variations in transfection efficiencies (Pfahl et al. 1990).

\section{Results}

\section{Influence of DES and OP on ER-a mRNA expression} in vivo

In situ hybridization and hence ER- $\alpha$ mRNA expression was demonstrated in all positive control sections of the adult uteri. Sections hybridized with sense probe did not exhibit hybridization (Fig. 1k).
The uterine epithelium of the control mice showed no sign of in situ hybridization and thus no presence of ER- $\alpha$ mRNA. Conversely, ER- $\alpha$ mRNA was highly expressed in the stroma (Fig. 1a). In both DES10 (Fig. 1c) and DES100 (Fig. 1e), the epithelium exhibited ER- $\alpha$ mRNA expression, whereas in OP100 (Fig. 1g) and OP250 (Fig. 1i) no expression was observed in this compartment. The ER- $\alpha$ mRNA expression in the stroma of both of the DES- and OP-treated animals (Fig. 1c, e, g, i) was high and did not appear to differ from the expression in control mice (Fig. 1a).

\section{Influence of DES and OP on ER-a protein expression in vivo}

In uteri from 18-19-day-old prepubertal mice all nuclei, but not the cytoplasm, exhibited stained reaction product. Nuclear staining was absent in control sections incubated without antibody (Fig. 11) or supplemented with irrelevant mouse-IgG. No significant differences between median absorbance values could be identified when sections from all control mice were run in one sitting and compared with sections from control mice stained on different days. This applied to both epithelial and stromal cell nuclei.

There was no apparent stain in epithelial cell nuclei from control, OP100 or OP250 mice (Fig. 1b, h, j). However, in both DES10 and DES100 mice, several epithelial cell nuclei revealed staining (Fig. 1d, f). In agreement with these observations made by inspecting the sections in the light microscope, only a very low median absorbance was recorded in epithelial cell nuclei from the control group, OP100 and OP250 mice (Fig. 2). Moreover, there was no significant difference between the median absorbance values of these groups. In contrast, the median absorbance of both DES10 and DES 100 epithelial cell nuclei increased significantly (Fig. 2).

In both exposed and control mice, a pronounced staining was seen in virtually all stroma cell nuclei (Fig. 1b, d, f, h, j). No significant differences could be identified when the median absorbance values of stroma cell nuclei in the different experimental groups were compared (Fig. 2).

\section{The DES and OP batches possess oestrogen-like activity in vitro}

The tested compounds stimulated transcriptional activity in vitro (Fig. 3). For the various concentrations tested, the

\footnotetext{
Figure 1 ER- $\alpha$ expression in uteri of newborn mice exposed prenatally to vehicle alone (a, b), $10 \mu g$ DES/kg (c, d), $100 \mu g$ DES/kg (e, f), $100 \mathrm{mg} \mathrm{OP} / \mathrm{kg}(\mathrm{g}, \mathrm{h})$ or $250 \mathrm{mg} \mathrm{OP} / \mathrm{kg}(\mathrm{i}, \mathrm{j})$. ER- $\alpha$ mRNA expression is detected by in situ hybridization $(\mathrm{a}, \mathrm{c}, \mathrm{e}, \mathrm{g}, \mathrm{i}, \mathrm{k})$ and ER- $\alpha$ protein by immunohistochemistry $(b, d, f, h, j, l)$. In control mice treated with vehicle alone $(a, b)$ and in OP-treated mice (g-j), neither ER- $\alpha$ mRNA or protein is expressed in the epithelium, whereas a high expression of both is present in the stroma. In DES-treated mice (c- $\mathrm{f}$ ) both ER- $\alpha$ mRNA and protein is detected in the epithelium, and the stroma exhibits a high expression. Control sections either hybridized with sense probe $(\mathrm{k})$ or incubated in 1\% BSA without ER antibody (l) show no expression of ER- $\alpha$ mRNA or protein respectively. The scale bar represents $30 \mu \mathrm{m}$.
} 


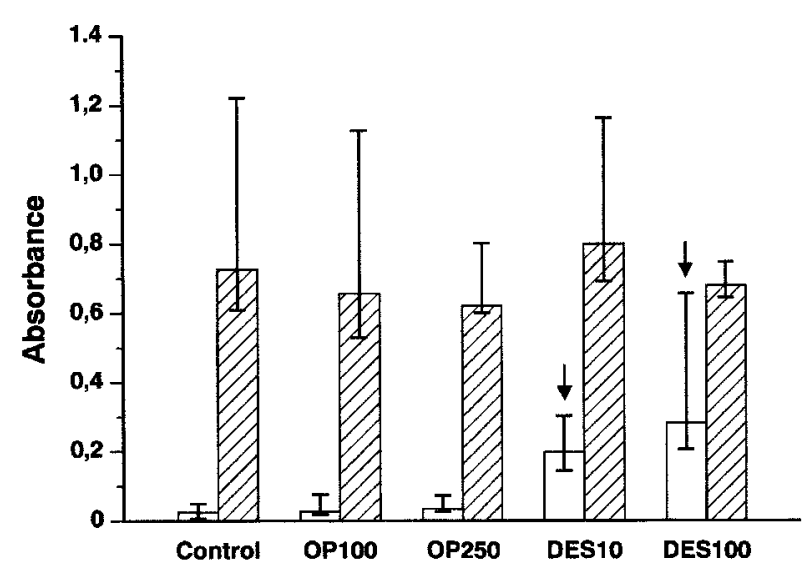

Figure 2 Quantitation of ER- $\alpha$ expression in immunostained sections from newborn mouse uteri after prenatal exposure to $10 \mu \mathrm{g}$ DES/kg (DES10), $100 \mu \mathrm{g}$ DES/kg (DES100), $100 \mathrm{mg} \mathrm{OP} / \mathrm{kg}$ (OP100), $250 \mathrm{mg} \mathrm{OP} / \mathrm{kg}$ (OP250) or vehicle alone (Control). Open bars show ER- $\alpha$ expression in epithelial cell nuclei. Hatched bars show ER- $\alpha$ expression in stroma cell nuclei. Results are indicated as medians of specific absorbances (total absorbances minus background absorbances) and ranges. Vertical arrows indicate medians that are significantly different from those calculated for the control animals, as evaluated a posteriori using a 95\% confidence limit level.

activity is shown as percentage of the maximal induction by $E_{2}$. The results are from two separate experiments in which each concentration was employed in triplicate. The half maximal activity for DES was reached at an approximately 1000 times lower concentration compared with

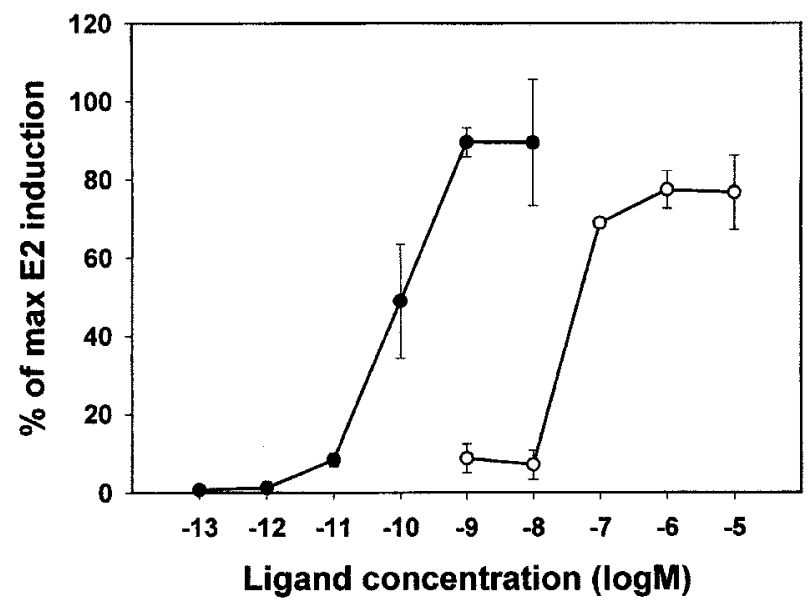

Figure 3 Transcriptional activity of DES and OP in 293 human embryonal kidney cells. Cells were transfected with ERE-TATA-luciferase reporter plasmid and human ER- $\alpha$. The transcriptional activity is given as a percentage \pm S.D. of the maximal induction by $E_{2}$. The data are from two separate experiments in which each concentration was employed in triplicate. DES $(\bullet)$ and OP $(\bigcirc)$.
OP. Nevertheless, both compounds induced transcription and thus demonstrated oestrogen-like activity in vitro.

\section{Discussion}

Application of ER- $\alpha$ specific antibodies and quantitation based on absorbance measurements has made it possible to distinguish objectively differences in immunostaining of this nuclear oestrogen receptor. Previous comparable studies have not discriminated between the subtypes of the nuclear oestrogen receptors, and evaluations of immunostaining have been based on subjective visual inspection of the sections. Mouse strain differences in neonatal ontogeny of oestrogen receptors in the uterine epithelium have been reported (Bigsby et al. 1990). Nevertheless, the lack of epithelial oestrogen receptors and relatively high expression in the stroma until around day 5 after birth is common (Cunha et al. 1982, Bigsby \& Cunha 1986, Andersson \& Forsberg 1988, Yamashita et al. 1989, Greco et al. 1991, Sato et al. 1992, 1996, Newbold 1995, Eroschenko et al. 1996, Nielsen et al. 2000). In the present study, a very low absorbance was measured in the uterine epithelium of the control animals. However, upon visual examination the epithelium appeared immunonegative, which is consistent with earlier observations. Our finding that expression of ER- $\alpha$ mRNA and protein is induced in the uterine epithelium after prenatal DES exposure is in accordance with previous reports employing prenatal (Newbold 1995) and neonatal DES exposure (Andersson \& Forsberg 1988, Sato et al. 1992, 1996). However, the unchanged ER- $\alpha$ immunostaining in the stroma after DES treatment contradicts previous data which by visual inspection describe an apparent decreased immunostaining in this compartment (Sato et al. 1992, 1996, Newbold 1995). It is interesting that the stroma and epithelial cells respond differently on DES exposure. Although ER- $\alpha$ is highly expressed in the stroma cells, it does not seem to participate in the regulation of its own expression in these cells. On the other hand, it is suggested that ER- $\alpha$ in the stroma cells could be involved in a paracrine regulation of ER- $\alpha$ in the epithelial cells. In fact, it was recently demonstrated that uterine epithelial progesterone receptors are regulated in a paracrine manner via ER- $\alpha$ in the stroma (Kurita et al. 2000).

In contrast to DES, OP does not induce the expression of either ER- $\alpha$ mRNA or protein in the uterine epithelium, although the in vitro data confirmed oestrogenlike activity of the OP batch. In the stroma, the immunostaining decreases slightly in a dose-dependent manner but the difference is not statistically significant. Neonatal exposure to the oestrogenic endocrine disruptor methoxychlor has been demonstrated to induce oestrogen receptor protein and mRNA expression in the murine uterine epithelium (Eroschenko et al. 1996). It is interesting that two different reported oestrogenic compounds do 
not induce the same change in oestrogen receptor expression. However, it is difficult to compare the methoxychlor data and data from our OP-exposed animals due to differences in exposure periods.

Although our in vivo data do not demonstrate a DESlike action of $\mathrm{OP}$, we cannot rule out the possibility that it may have oestrogen-like effects in mice. In addition to the numerous in vitro studies identifying $\mathrm{OP}$ as weakly oestrogenic, other rodent studies have demonstrated its oestrogen-like effects in vivo. These studies have primarily focused on effects in males after exposure during either foetal life (Sharpe et al. 1995, Majdic et al. 1996, 1997, vom Saal et al. 1998) or adulthood (Blake \& Boockfor 1997, Boockfor \& Blake 1997). Foetal exposure was carried out by exposing the mothers orally by adding OP to the drinking water $(100-1000 \mu \mathrm{g} O P / 1$ water) (Sharpe et al. 1995) or by delivering OP dissolved in oil $(2 \mu \mathrm{g} / \mathrm{kg}$ maternal wt) directly into the mouth daily from 11 to 17 p.c. (vom Saal et al. 1998). Others subcutaneously injected the pregnant mothers day 11.5 and $15 \cdot 5$ p.c. with 100 or $600 \mathrm{mg} \mathrm{OP} / \mathrm{kg}$ maternal wt (Majdic et al. 1996, 1997). Adult males were subcutaneously injected with 20 or $80 \mathrm{mg}$ OP three times weekly for 1-2 months (Blake \& Boockfor 1997, Boockfor \& Blake 1997). The observed effects include changes in the morphology as well as reduced weight of testes and accessory sex organs, decreased sperm production and altered secretion of reproductive hormones (Sharpe et al. 1995, Blake \& Boockfor 1997, Boockfor \& Blake 1997, vom Saal et al. 1998). In addition, the expression of P450 17 $\alpha$ hydroxylase/C17-20-lyase and steroidogenic factor 1 in the testis appears to be affected (Majdic et al. 1996, 1997). In neonatal and prepubertal female rats subcutaneously injected with 1-30 $\mathrm{mg} \mathrm{OP}$, the uterine weight increases (Bicknell et al. 1995) and the oestrous cyclicity is disrupted, identified by the persistent presence of cornified cells (Blake \& Ashiru 1997). One explanation for why OP did not exhibit an in vivo oestrogen-like effect in the present study could be that the mechanisms behind the induction of ER- $\alpha$ expression differs from those involved in the regulation of uterus weight and oestrous cyclicity. Furthermore, compared with the previous studies in neonatal and prepubertal female rats, the present study employed prenatal exposure, which could result in reduced OP exposure levels due to OP metabolism in the mother or insufficient placental transfer of OP. However, as mentioned, prenatally OP exposed male rodents have been shown to develop abnormalities. When comparing studies of OP-induced effects in prenatally exposed females and males it is important to bear in mind that under normal circumstances the in utero level of oestrogens is lower in males compared with females (vom Saal et al. 1983). Therefore, male foetuses may be relatively sensitive to changes in levels of oestrogens and/or oestrogen-like compounds. Furthermore, comparison between data obtained in rats and mice and even in different mouse strains should be done with care. Recently, it was shown that among different mouse strains oestrogen responsiveness could differ due to different genetic regulation (Roper et al. 1999, Spearow et al. 1999).

When studying endocrine disruptors and their possible contribution to the development of structural and functional reproductive abnormalities, it is important to investigate them in the context of relevant parameters. The incidence of uterine structural abnormalities is elevated among mice and humans exposed prenatally to DES (Kaufman et al. 1977, Haney et al. 1979, McLachlan et al. 1980, Newbold 1995). Moreover, in such mice, long-term effects include uterine tumours (McLachlan et al. 1980, Newbold 1995) and altered uterine protein secretion (Maier et al. 1985). It is therefore relevant to ask whether changes in uterine ER- $\alpha$ expression may be involved in such abnormalities.

It has been shown that an increased level of oestrogen receptors is involved in the development of uterine tumours (Couse et al. 1997). In transgenic mice with an aberrant expression of oestrogen receptors, neonatal DES treatment leads to accelerated tumour development in adulthood. The level of oestrogen receptors was hence suggested to be involved in the proliferation of tumours induced by early DES exposure. However, the uterine epithelial oestrogen receptors may not be significant for epithelial cell proliferation. In the uterus of normal adult mice, oestrogen has been shown to stimulate epithelial cell proliferation in a paracrine manner via the stroma cells, in a process in which neither epithelial ER- $\alpha$ nor ER- $\beta$ is necessary or sufficient (Cooke et al. 1997). Consequently, the content of oestrogen receptors in an epithelial cell might not, at least in adults, determine its oestrogeninduced proliferative activity.

DES treatment of neonatal mice induces production of the secretory protein lactoferrin in the uterine epithelium (Yamashita et al. 1990, Nelson et al. 1994). Cells which express lactoferrin always express oestrogen receptors that are induced before lactoferrin, and epithelial oestrogen receptors are therefore suggested to be a prerequisite for expression of lactoferrin (Yamashita et al. 1990). Recently, it has been shown that both stromal and epithelial ER- $\alpha$ are involved in the production of oestrogen-dependent uterine secretory proteins (Buchanan et al. 1999). Altered uterine protein secretion throughout adulthood after DES treatment prenatally (Maier et al. 1985) or neonatally (Yamashita et al. 1990, Nelson et al. 1994) may thus involve a perinatal induction of ER- $\alpha$ expression in the otherwise ER- $\alpha$ devoid uterine epithelium. However, recent data suggest that endocrine disruptors and catechol oestrogens are able to induce oestrogen-responsive uterine genes, including lactoferrin via an alternative, unknown pathway which does not require ER- $\alpha$ or ER- $\beta$ (Das et al. 1998, Ghosh et al. 1999).

Although OP does not induce ER- $\alpha$ expression, it cannot be eliminated as an endocrine disruptor with 
potential oestrogen-like activity affecting the female genital tract. Alterations may be induced via other mechanisms and pathways which do not involve epithelial ER- $\alpha$ and its induction. Moreover, effects induced by exposure in foetal life might not become evident until later in life. It is therefore crucial to extend studies of the prenatally exposed animals to include older animals, as well as widening the range of effect parameters.

\section{Acknowledgements}

The Danish Environmental Research Programme: Danish Centre for Environmental Oestrogen Research, and The Danish Medical Research Councils no. 9700832, and The Environmental Climate Programme ENV4-CT96-0240 supported this study. We thank Keld Ottosen and Sóley Björnsdóttir for expert technical assistance.

\section{References}

Al Saati T, Clamens S, Cohen-Knafo E, Faye JC, Prats H, Coindre JM, Wafflart J, Caveriviere P, Bayard F \& Delsol G 1993 Production of monoclonal antibodies to human estrogen-receptor protein (ER) using recombinant ER (RER). International Journal of Cancer 55 651-654.

Andersson C \& Forsberg JG 1988 Induction of estrogen receptor, peroxidase activity, and epithelial abnormalities in the mouse uterovaginal epithelium after neonatal treatment with diethylstilbestrol. Teratogenesis, Carcinogenesis, and Mutagenesis $\mathbf{8}$ 347-361.

Arnold SF, Robinson MK, Notides AC, Guillette LJJ \& McLachlan JA 1996 A yeast estrogen screen for examining the relative exposure of cells to natural and xenoestrogens. Environmental Health Perspectives 104 544-548.

Bern HA 1992 The fragile fetus. In Chemically Induced Alterations in Sexual and Functional Development: The Wildlife/Human Connection, pp. 9-15. Eds T Colborn \& C Clement. Princeton, NJ: Princeton Scientific Publishing.

Bibbo M, Gill WB, Azizi F, Blough R, Fang VS, Rosenfield RL, Schumacher GF, Sleeper K, Sonek MG \& Wied GL 1977 Follow-up study of male and female offspring of DES-exposed mothers. Obstetrics and Gynecology 49 1-8.

Bicknell RJ, Herbison AE \& Sumpter JP 1995 Oestrogenic activity of an environmentally persistent alkylphenol in the reproductive tract but not the brain of rodents. Journal of Steroid Biochemistry and Molecular Biology 54 7-9.

Bigsby RM \& Cunha GR 1986 Estrogen stimulation of deoxyribonucleic acid synthesis in uterine epithelial cells which lack estrogen receptors. Endocrinology 119 390-396.

Bigsby RM, Li AX, Luo K \& Cunha GR 1990 Strain differences in the ontogeny of estrogen receptors in murine uterine epithelium. Endocrinology 126 2592-2596.

Blake CA \& Ashiru OA 1997 Disruption of rat estrous cyclicity by the environmental estrogen 4-tert-octylphenol. Proceedings of The Society For Experimental Biology and Medicine 216 446-451.

Blake CA \& Boockfor FR 1997 Chronic administration of the environmental pollutant 4-tert-octylphenol to adult male rats interferes with the secretion of luteinizing hormone, follicle-stimulating hormone, prolactin, and testosterone. Biology of Reproduction 57 255-266.

Boockfor FR \& Blake CA 1997 Chronic administration of 4-tert-octylphenol to adult male rats causes shrinkage of the testes and male accessory sex organs, disrupts spermatogenesis, and increases the incidence of sperm deformities. Biology of Reproduction 57 267-277.

Buchanan DL, Setiawan T, Lubahn DB, Taylor JA, Kurita T, Cunha GR \& Cooke PS 1999 Tissue compartment-specific estrogen receptor- $\alpha$ participation in the mouse uterine epithelial secretory response. Endocrinology 140 484-491.

Chu G \& Sharp PA 1981 SV40 DNA transfection of cells in suspension: analysis of efficiency of transcription and translation of T-antigen. Gene 13 197-202.

Coldham NG, Dave M, Sivapathasundaram S, McDonnell DP, Connor C \& Sauer MJ 1997 Evaluation of a recombinant yeast cell estrogen screening assay. Environmental Health Perspectives 105 734-742.

Conover WJ 1980 Practical Nonparametric Statistics. New York: John Wiley \& Sons.

Cooke PS, Buchanan DL, Young P, Setiawan T, Brody J, Korach KS, Taylor J, Lubahn DB \& Cunha GR 1997 Stromal estrogen receptors mediate mitogenic effects of estradiol on uterine epithelium. PNAS 94 6535-6540.

Couse JF, Davis VL, Hanson RB, Jefferson WN, McLachlan JA, Bullock BC, Newbold RR \& Korach KS 1997 Accelerated onset of uterine tumors in transgenic mice with aberrant expression of the estrogen receptor after neonatal exposure to diethylstilbestrol. Molecular Carcinogenesis 19 236-242.

Crisp TM, Clegg ED, Cooper RL, Wood WP, Anderson DG, Baetcke KP, Hoffmann JL, Morrow MS, Rodier DJ, Schaeffer JE, Touart LW, Zeeman MG \& Patel YM 1998 Environmental endocrine disruption: an effects assessment and analysis [see comments]. Environmental Health Perspectives 106 (Suppl 1) $11-56$.

Cunha GR, Shannon JM, Vanderslice KD, Sekkingstad M \& Robboy SJ 1982 Autoradiographic analysis of nuclear estrogen binding sites during postnatal development of the genital tract of female mice. Journal of Steroid Biochemistry 17 281-286.

Das SK, Tan J, Johnson DC \& Dey SK 1998 Differential spatiotemporal regulation of lactoferrin and progesterone receptor genes in the mouse uterus by primary estrogen, catechol estrogen, and xenoestrogen. Endocrinology 139 2905-2915.

Eroschenko VP, Rourke AW \& Sims WF 1996 Estradiol or methoxychlor stimulates estrogen receptor (ER) expression in uteri. Reproductive Toxicology 10 265-271.

Feijen A, Goumans MJ \& van den Eijnden-van Raaij AJ 1994 Expression of activin subunits, activin receptors and follistatin in postimplantation mouse embryos suggests specific developmental functions for different activins. Development 120 3621-3637.

Ghosh D, Taylor JA, Green JA \& Lubahn DB 1999 Methoxychlor stimulates estrogen-responsive messenger ribonucleic acids in mouse uterus through a non-estrogen receptor (non-ER) $\alpha$ and non-ER $\beta$ mechanism. Endocrinology 140 3526-3533.

Gill WB, Schumacher GF, Bibbo M, Straus FH \& Schoenberg HW 1979 Association of diethylstilbestrol exposure in utero with cryptorchidism, testicular hypoplasia and semen abnormalities. Journal of Urology 122 36-39.

Greco TL, Furlow JD, Duello TM \& Gorski J 1991 Immunodetection of estrogen receptors in fetal and neonatal female mouse reproductive tracts. Endocrinology 129 1326-1332.

Haney AF, Hammond CB, Soules MR \& Creasman WT 1979 Diethylstilbestrol-induced upper genital tract abnormalities. Fertility and Sterility 31 142-146.

Kaufman RH, Binder GL, Gray PMJ \& Adam E 1977 Upper genital tract changes associated with exposure in utero to diethylstilbestrol. American Journal of Obstetrics and Gynecology 128 51-59.

Kuiper GG, Enmark E, Pelto-Huikko M, Nilsson S \& Gustafsson JA 1996 Cloning of a novel receptor expressed in rat prostate and ovary. PNAS 93 5925-5930. 
Kuiper GG, Lemmen JG, Carlsson B, Corton JC, Safe SH, van der Saag PT, van der Burg B \& Gustafsson JA 1998 Interaction of estrogenic chemicals and phytoestrogens with estrogen receptor $\beta$. Endocrinology 139 4252-4263.

Kurita T, Lee K, Cooke PS, Taylor JA, Lubahn DB \& Cunha GR 2000 Paracrine regulation of epithelial progesterone receptor by estradiol in the mouse female reproductive tract. Biology of Reproduction 62 821-830.

Legler J, van den Brink CE, Brouwer A, Murk AJ, van der Saag PT, Vethaak AD \& van der Burg B 1999 Development of a stably transfected estrogen receptor-mediated luciferase reporter gene assay in the human T47D breast cancer cell line. Toxicological Sciences $\mathbf{4 8}$ 55-66.

Lemmen JG, Broekhof JL, Kuiper GG, Gustafsson JA, van der Saag PT \& van der Burg B 1999 Expression of estrogen receptor alpha and beta during mouse embryogenesis. Mechanisms of Development 81 163-167.

Maier DB, Newbold RR \& McLachlan JA 1985 Prenatal diethylstilbestrol exposure alters murine uterine responses to prepubertal estrogen stimulation. Endocrinology 116 1878-1886.

Majdic G, Sharpe RM, O’Shaughnessy PJ \& Saunders PT 1996 Expression of cytochrome P450 17 alpha-hydroxylase/C17-20 lyase in the fetal rat testis is reduced by maternal exposure to exogenous estrogens. Endocrinology 137 1063-1070.

Majdic G, Sharpe RM \& Saunders PT 1997 Maternal oestrogen/ xenoestrogen exposure alters expression of steroidogenic factor-1 (SF-1/Ad4 BP) in the fetal rat testis. Molecular and Cellular Endocrinology 127 91-98.

Makela S, Davis VL, Tally WC, Korkman J, Salo L, Vihko R, Santti R \& Korach KS 1994 Dietary estrogens act through estrogen receptor-mediated processes and show no antiestrogenicity in cultured breast cancer cells. Environmental Health Perspectives 102 572-578.

McLachlan JA, Newbold RR \& Bullock B 1975 Reproductive tract lesions in male mice exposed prenatally to diethylstilbestrol. Science 190 991-992.

McLachlan JA, Newbold RR \& Bullock BC 1980 Long-term effects on the female mouse genital tract associated with prenatal exposure to diethylstilbestrol. Cancer Research 40 3988-3999.

Mosselman S, Polman J \& Dijkema R 1996 ER $\beta$ : identification and characterization of a novel human estrogen receptor. FEBS Letters 392 49-53.

Nelson KG, Sakai Y, Eitzman B, Steed T \& McLachlan J 1994 Exposure to diethylstilbestrol during a critical developmental period of the mouse reproductive tract leads to persistent induction of two estrogen-regulated genes. Cell Growth and Differentiation 5 595-606.

Nemere I \& Farach-Carson MC 1998 Membrane receptors for steroid hormones: a case for specific cell surface binding sites for vitamin D metabolites and estrogens. Biochemical and Biophysical Research Communication 248 443-449.

Newbold R 1995 Cellular and molecular effects of developmental exposure to diethylstilbestrol: implications for other environmental estrogens. Environmental Health Perspectives 103 (Suppl 7) 83-87.

Nielsen M, Björnsdóttir S, Høyer PE \& Byskov AG 2000 The ontogeny of oestrogen receptor $\alpha$ in gonads and sex ducts of fetal and newborn mice. Journal of Reproduction and Fertility 118 195-204.

Pelissero C, Flouriot G, Foucher JL, Bennetau B, Dunogues J, Le Gac F \& Sumpter JP 1993 Vitellogenin synthesis in cultured hepatocytes; an in vitro test for the estrogenic potency of chemicals. Journal of Steroid Biochemistry and Molecular Biology 44 263-272.
Pettersson K, Grandien K, Kuiper GG \& Gustafsson JA 1997 Mouse estrogen receptor $\beta$ forms estrogen response element-binding heterodimers with estrogen receptor $\alpha$. Molecular Endocrinology 11 1486-1496.

Pfahl M, Tzukerman M, Zhang XK, Lehmann JM, Hermann T, Wills KN \& Graupner G 1990 Nuclear retinoic acid receptors: cloning, analysis, and function. Methods in Enzymology 189 256-270.

Roper RJ, Griffith JS, Lyttle CR, Doerge RW, McNabb AW, Broadbent RE \& Teuscher C 1999 Interacting quantitative trait loci control phenotypic variation in murine estradiol-regulated responses. Endocrinology 140 556-561.

Sato T, Okamura H, Ohta Y, Hayashi S, Takamatsu Y, Takasugi N \& Iguchi T 1992 Estrogen receptor expression in the genital tract of female mice treated neonatally with diethylstilbestrol. In Vivo 6 151-156.

Sato T, Ohta Y, Okamura H, Hayashi S \& Iguchi T 1996 Estrogen receptor (ER) and its messenger ribonucleic acid expression in the genital tract of female mice exposed neonatally to tamoxifen and diethylstilbestrol. Anatomical Record 244 374-385.

Sharpe RM, Fisher JS, Millar MM, Jobling S \& Sumpter JP 1995 Gestational and lactational exposure of rats to xenoestrogens results in reduced testicular size and sperm production. Environmental Health Perspectives 103 1136-1143.

Soto AM, Sonnenschein C, Chung KL, Fernandez MF, Olea N \& Serrano FO 1995 The E-SCREEN assay as a tool to identify estrogens: an update on estrogenic environmental pollutants. Environmental Health Perspectives 103 (Suppl 7) 113-122.

Spearow JL, Doemeny P, Sera R, LefflerR \& Barkley M 1999 Genetic variation in susceptibility to endocrine disruption by estrogen in mice [see comments]. Science 285 1259-1261.

Tremblay GB, Tremblay A, Copeland NG, Gilbert DJ, Jenkins NA, Labrie F \& Giguere V 1997 Cloning, chromosomal localization, and functional analysis of the murine estrogen receptor $\beta$. Molecular Endocrinology 11 353-365.

vom Saal F, Grant WM, McMullen CW \& Laves KS 1983 High fetal estrogen concentrations: correlation with increased adult sexual activity and decreased aggression in male mice. Science $\mathbf{2 2 0}$ 1306-1309.

vom Saal F, Cooke PS, Buchanan DL, Palanza P, Thayer KA, Nagel SC, Parmigiani S \& Welshons WV 1998 A physiologically based approach to the study of bisphenol A and other estrogenic chemicals on the size of reproductive organs, daily sperm production, and behavior. Toxicology and Industrial Health 14 239-260.

White R, Jobling S, Hoare SA, Sumpter JP \& Parker MG 1994 Environmentally persistent alkylphenolic compounds are estrogenic. Endocrinology 135 175-182.

Wilcox AJ, Baird DD, Weinberg CR, Hornsby PP \& Herbst AL 1995 Fertility in men exposed prenatally to diethylstilbestrol. New England Journal of Medicine 332 1411-1416.

Yamashita S, Newbold RR, McLachlan JA \& Korach KS 1989 Developmental pattern of estrogen receptor expression in female mouse genital tracts. Endocrinology 125 2888-2896.

Yamashita S, Newbold RR, McLachlan JA \& Korach KS 1990 The role of the estrogen receptor in uterine epithelial proliferation and cytodifferentiation in neonatal mice. Endocrinology 127 2456-2463.

Received 3 March 2000

Accepted 5 June 2000 